\title{
OCCUPATIONAL INJURIES AMONG MARBLE AND GRANITE PROCESSING WORKERS: A COMPARATIVE STUDY
}

\author{
By \\ Kamel NM, Sleem AN, Kamel EA and Elsherbeny EE \\ Department of Industrial Medicine and Occupational Health, Public Health and Community \\ Medicine, Faculty of Medicine, Mansoura University, Mansoura, Egypt. \\ Corresponding author: Elsherbeny EE.E mail:enass75@mans.edu.eg
}

Submit Date: 2021-04-14

Revise Date: 2021-05-23

Accept Date: 2021-05-31

DOI: $10.21608 /$ ejom.2021.71908.1231

Author contributions: Kamel NM: Data collection and writing the manuscript, data analysis and interpretation. Sleem AN and Kamel EA: Drafting and revising the manuscript.

Elsherbeny EE: Writing, revising and submission of the manuscript.

\begin{abstract}
Introduction: Marble and Granite are natural stones that can be shaped into blocks, slabs or tiles. Their production passes through several stages. The production process could result in many injuries. Aim of Work: to detect the prevalence of workplace injuries, their predictors and causes among marble and granite workers. Materials and Methods: A descriptive comparative cross-sectional study was conducted in four workshops at Damietta Governorate from June 1, 2016 to May 30, 2017. The studied groups were composed of an exposed group engaged in the marble and granite processing and a comparison one who were not engaged in this industry (each group comprises of 90 workers). They were subjected to an interview questionnaire asking about sociodemographic characteristics, occupational profile, injury profile and their anthropometric measurements were taken. Results: All marble and granite workers experienced one or more injuries in the past year compared to $(13.3 \%)$ of the comparison group with highly statistically significant difference $(p \leq 0.001)$. They showed high prevalence of superficial wounds, contusion/bruises, tear and laceration compared to the control group. Unsafe working environment, using inappropriate instruments, lack of protective equipment and nonadherence to
\end{abstract}




\begin{abstract}
donning them were the main causes of workplace injuries. Regarding predictors for injuries, workers with low income (being in debt) are 18 times prone to injures than those who can save money. Current smokers are 7.6 times than nonsmokers, unmarried workers are 6.61 times than married and who live in rural areas are 4.43 times than others who live in urban areas. Conclusion: Providing safe working environment, donning suitable protective equipment, implementing effective training programs for all workers especially high-risk ones are crucial preventive measures. Keywords: Marble and Granite, Occupational injuries, Protective equipment and Smoker.
\end{abstract}

\section{Introduction}

Marble and Granite belong to the category of building stones widely known as Dimension Stone. These are natural stones which can be shaped in the form of blocks, slabs, tiles and are mostly used for monumental and decorative purposes since antiquity. (Trade Development Authority of Pakistan, 2011). According to Kandil and Selim (2006), the production of marble passes through several stages starting with exploration followed by extraction, lifting, transportation, inventory management, processing in the form of blocks cutting and polishing, and finally cutting into slabs for distribution. Stonecutting is a lengthy process using diamond blades. The polishing operation is fully automated with the use of powdered abrasives until it becomes smooth and shiny.

Occupational injuries constitute a major portion of the global injury burden, comprising almost $30 \%$ of all medically treated injuries to persons aged 18 to 64 years (Brown, 2020). Globally, an estimated 2.3 million workers die every year from occupational accidents and work-related diseases (ILO, 2014 and Amponsah-Tawiah and Mensah, 2016). A study conducted among Stone Saw Workers in West Bank-Palestine found that around $35.9 \%$ of workers had sustained work related injury (Jaber et al., 2015). The impact is 10 to 20 times higher in developing countries, where the greatest concentration of the world's workforce is located and they don't have access to occupational health services (Tadesse and Kumie, 2007).

Stone-cutting machines with unguarded cutting blades can cause amputations and other serious injuries (OSHA, 2013). Serious injuries and fatalities also occur during handling of large heavy stone slabs (do Couto et al., 2018). ILO (2009) stated that, falling, either from heights or due to collapse of support, slips and falls on the level at the 
work site, falling objects, overexertion or strained movements throughout the lifting of heavy loads, working with mechanical and pneumatic equipment, getting hit by manual work tool and penetration of ricochets and stone splinters into the eyes are common occupational accidents and injuries among stone cutting workers.

To the best of the authors'knowledge, there were few conducted studies about injuries among marble and granite workers in Egypt. Damietta governate was chosen as it is a commercial city based on different activities of furniture workshops including painting and marble workshops (El-Gammal et al., 2011).

\section{Aim of Work}

The current study aims to detect the prevalence of workplace injuries and both their predictors and causes among marble and granite workers.

\section{Materials and Methods}

Study design: An observational descriptive comparative cross-sectional study.

Place and duration of the study: The study was conducted in four small-scale workshops in Damietta Governorate at the Northeast of Egypt; with a population of almost one million inhabitants. The study was conducted from June $1^{\text {st }}$ of 2016 to May $30^{\text {th }}$ of 2017.

Study population: The study comprises two groups of workers: (a) an exposed group, engaged in the marble and granite processing operations within the four workshops, and (b) a comparison group of workers from Damietta University of similar age and sociodemographic characteristics, not engaged in marble and granite processing. A convenience sample of 180 workers (90 in each group) was included.

Sampling method: The first workshop was chosen by convenience. While the remaining three workshops were chosen by snowball sampling. The total number of workers was 127; of whom 90 were included in the study (response rate $70.8 \%$ ). The excluded workers were 37 , of which 20 shared in the external pilot study and the rest (17 workers) refused to participate. An equal number of participants were recruited from the non-exposed group.

Pilot study: Before starting data collection, an external pilot study was carried out on 20 workers at the four workshops to test the clarity of the 
questions and estimate the time needed to fill the questionnaire by each worker.

Study tools: Each participant was subjected to

\section{I- An interview questionnaire} asking about: A) Sociodemographic characteristics (including age, gender, residence, marital status, level of education, family size, smoking status). B) Occupational profile (including type of contract, duration of employment, presence of shift work, presence of direct supervision at work). C) Workrelated injuries, which were assessed by a polar question (Yes/NO response); "Within the past 12 months, have you experienced any work-related injuries?". This question was prefaced by, "The following questions are about work-related injuries you have incurred within the past 12 months while working as a marble and granite processor." Those who reported a work-related injury were then asked about the injury location, activity being performed when injured, primary cause and type of injury and health and safety measures (including training courses on the use of chemicals, tools, emergency measures, and availability and usage of PPE). The asked questions were adapted from recommended practices for safety and health programs (OSHA, 2016).

\section{II-Anthropometric measurements}

taking: in the form of

- Weight: a portable scale was used. The participant was weighted barefooted and wearing light clothes. Height: the participant was asked to stand without shoes on a flat floor against the wall, with their feet parallel. Then, the height was measured from the level of the ground to the mark.

- Body mass index (BMI) measured in $\mathbf{k g} / \mathbf{m}^{2}$ : was calculated according the following equation: Body mass

$$
\text { index }=\frac{\text { (Body weight }(\mathrm{kg})}{\text { (Height in meter }) 2}
$$

Operational definitions: A workrelated injury was defined according to the Occupational Safety and Health Administration(OSHA, 2001) standards (1904.5a) in the questionnaire as, "An injury is considered work-related if an event or exposure in the work environment caused or contributed to the condition or significantly aggravated a pre-existing condition."

Normal range of BMI is 18.50 -24.99 , overweight if it is $\geq 25$, obese if it is $\geq 30$. 


\section{Consent}

An informed verbal consent was taken from all participants at the beginning of the study

with assurance of disclosure and anonymity of the data.

\section{Ethical Approval}

Study protocol was approved by Institutional Research Board (IRB) of Faculty of Medicine with code (MD/16.05.28), Mansoura University. Approval of the managerial authority of the workshops was attained.

\section{Data Management}

Data entry and statistical analysis were done using the Statistical Package for Social Science (SPSS) software program version 17 . Normality of continuous variables was checked by the Shapiro-Wilk test. Quantitative data were described as means and standard deviation (if parametric) or median and range (if non-parametric). Student t-test was used for quantitative normally distributed variables, and Mann Whitney $U$ test was used for non-parametric variables. Qualitative data were described as numbers and percentages. The Chi-square test was used for comparing qualitative variables. Logistic regression analysis was used to determine the predictors of occupational injuries among the affected workers. Statistical significance was set at $\mathrm{p}<0.05$. 


\section{Results}

Table (1): Socio-demographic characteristics of the studied groups.

\begin{tabular}{|c|c|c|c|}
\hline \multirow{2}{*}{ Characteristics } & $\begin{array}{c}\text { Marble \& } \\
\text { granite workers } \\
\text { No }=90\end{array}$ & $\begin{array}{c}\text { Comparison } \\
\text { group } \\
\text { No }=90 \\
\end{array}$ & Tests of Significance \\
\hline & No $(\%)$ & No $(\%)$ & \\
\hline \multicolumn{4}{|l|}{ Age (years) } \\
\hline $\begin{array}{l}<40 \\
\geq 40\end{array}$ & $\begin{array}{l}61(67.8) \\
29(32.2)\end{array}$ & $\begin{array}{l}58(64.4) \\
32(35.6)\end{array}$ & $\begin{array}{l}\chi^{2}=0.2, p>0.05 \\
\text { OR } 1.2(0.6-2.1)\end{array}$ \\
\hline Mean $\pm \mathrm{SD}$ (years) & $34.9 \pm 9.1$ & $37.3 \pm 9.2$ & $\mathrm{t}=1.7, \mathrm{p}>0.05$ \\
\hline \multicolumn{4}{|l|}{ Residence } \\
\hline $\begin{array}{l}\text { Rural } \\
\text { Urban }\end{array}$ & $\begin{array}{c}84(93.3) \\
6(6.7) \\
\end{array}$ & $\begin{array}{l}39(43.3) \\
51(56.7) \\
\end{array}$ & $\begin{array}{l}\chi^{2}=51.9, \mathbf{p} \leq \mathbf{0 . 0 0 1} * \\
\text { OR } 18.3(7.2-46.2)\end{array}$ \\
\hline \multicolumn{4}{|l|}{ Level of education } \\
\hline $\begin{array}{l}\text { Illiterate } \\
\text { Read and write }\end{array}$ & $\begin{array}{c}4(4.4) \\
86(95.6) \\
\end{array}$ & $\begin{array}{c}0(0) \\
90(100) \\
\end{array}$ & Fisher $<$ s exact, $\mathrm{p}>0.05$ \\
\hline \multicolumn{4}{|l|}{ Family size } \\
\hline $\begin{array}{l}<5 \text { persons } \\
\geq 5 \text { persons }\end{array}$ & $\begin{array}{l}41(45.6) \\
49(54.4) \\
\end{array}$ & $\begin{array}{l}53(58.9) \\
37(41.1) \\
\end{array}$ & $\begin{array}{l}\chi^{2}=3.2, p>0.05 \\
\text { OR } 0.5(0.3-1.1)\end{array}$ \\
\hline \multicolumn{4}{|l|}{ Family income per month } \\
\hline $\begin{array}{l}\text { Able to save } \\
\text { Enough } \\
\text { In debt }\end{array}$ & $\begin{array}{c}1(1.1) \\
36(40.0) \\
53(58.9) \\
\end{array}$ & $\begin{array}{l}13(14.4) \\
48(53.3) \\
29(32.2) \\
\end{array}$ & $\chi^{2}=19.02, \mathbf{p} \leq \mathbf{0 . 0 0 1}$ * \\
\hline \multicolumn{4}{|l|}{ Marital status } \\
\hline $\begin{array}{l}\text { Unmarried } \\
\text { Married }\end{array}$ & $\begin{array}{l}26(28.9) \\
64(71.1) \\
\end{array}$ & $\begin{array}{c}8(8.9) \\
82(91.1) \\
\end{array}$ & $\begin{array}{c}\chi^{2}=11.7, \quad \mathbf{p} \leq \mathbf{0 . 0 0 1 *} \\
\text { OR } 4.1(1.7-9.8)\end{array}$ \\
\hline \multicolumn{4}{|l|}{ Current Smoking habits } \\
\hline $\begin{array}{l}\text { Yes } \\
\text { NO }\end{array}$ & $\begin{array}{l}74(82.2) \\
16(7.8) \\
\end{array}$ & $\begin{array}{l}27(30.0) \\
63(70.0) \\
\end{array}$ & $\begin{array}{l}\chi^{2}=49.8, \mathbf{p} \leq \mathbf{0 . 0 0 1 *} \\
\text { OR } 10.7(5.3-21.8)\end{array}$ \\
\hline \multicolumn{4}{|c|}{ Number of cigarettes /day } \\
\hline $\begin{array}{l}\leq 10 \\
>10\end{array}$ & $\begin{array}{c}16(22.9) \\
54(77.1) \\
\end{array}$ & $\begin{array}{c}9(34.6) \\
17(65.4)\end{array}$ & $\begin{array}{l}\chi^{2}=1.3, p>0.05 \\
\text { OR } 0.5(0.2-1.4)\end{array}$ \\
\hline $\begin{array}{l}\text { Duration of smoking } \\
\text { Median (Min - Max) }\end{array}$ & $15(2-36)$ & $15(5-35)$ & $\mathrm{Z}^{\#}=0.4, \mathrm{p}>0.05$ \\
\hline
\end{tabular}

$\mathrm{SD}=$ standard deviation $\mathrm{Min}=$ minimum, $\mathrm{p}=$ probability $\quad$ \#Z of Mann Whitney test
Max=maximum OR =odds ratio

*: statistically significant difference. 
Table (1) showed that both the studied groups were below 40 years old $(67.8 \%$, $64.4 \%$ respectively). All were males and most of them were married. Most of the marble and granite workers $(93.3 \%)$ were from rural areas compared to $(43.3 \%)$ of the comparison group with statistically significant difference. About half of the marble and granite workers had low family income compared to one third of the control group with $\mathrm{p} \leq 0.001$. More than three quarters of the marble and granite workers were current smokers compared to one third of the comparison group with $\mathrm{p} \leq 0.001$. The median duration of smoking was 15 years.

Table (2): Occupational profile of the studied groups.

\begin{tabular}{|c|c|c|c|}
\hline \multirow[t]{2}{*}{ Parameters } & $\begin{array}{c}\text { Marble } \& \\
\text { granite workers } \\
\text { No }=90 \\
\end{array}$ & $\begin{array}{c}\text { Comparison } \\
\text { group } \\
\text { No }=\mathbf{9 0} \\
\end{array}$ & \multirow[t]{2}{*}{ Tests of significance } \\
\hline & No $(\%)$ & No $(\%)$ & \\
\hline \multicolumn{4}{|l|}{ Type of contract } \\
\hline $\begin{array}{l}\text { - Permanent } \\
\text { - Temporary }\end{array}$ & $\begin{array}{l}79(87.8) \\
11(12.2)\end{array}$ & $\begin{array}{l}77(85.6) \\
13(14.4)\end{array}$ & $\begin{array}{l}\chi^{2}=0.2, p>0.05 \\
\text { OR } 1.2(0.5-2.8)\end{array}$ \\
\hline $\begin{array}{l}\text { Duration of employment/yrs } \\
\text { Median (Min - Max) }\end{array}$ & $12(3-31)$ & $10(3-35)$ & $\mathrm{Z}^{\#}=1.4, \mathrm{p}>0.05$ \\
\hline $\begin{array}{l}\text { Age of joining current occupation/ } \\
\text { yrs }(\text { Mean } \pm \text { SD) }\end{array}$ & $21.3 \pm 3.9$ & $25.1 \pm 4.5$ & $\mathrm{t}=5.9, \mathbf{p} \leq \mathbf{0 . 0 0 1} *$ \\
\hline Working in shifts & $90(100)$ & $90(100)$ & ---------------- \\
\hline \multicolumn{4}{|l|}{ Other jobs } \\
\hline Current & $24(26.7)$ & $32(35.6)$ & $\begin{array}{l}\chi^{2}=1.6, p>0.05 \\
\text { OR } 0.6(0.3-1.2)\end{array}$ \\
\hline Past & $34(37.8)$ & $33(36.7)$ & $\begin{array}{l}\chi^{2}=0.02, p>0.05 \\
\text { OR } 1.04(0.5-1.9)\end{array}$ \\
\hline \multicolumn{4}{|l|}{ Having direct supervision on work } \\
\hline $\begin{array}{l}\text { Yes } \\
\text { NO }\end{array}$ & $\begin{array}{c}86(95.6) \\
4(4.4)\end{array}$ & $\begin{array}{c}90(100) \\
0(0)\end{array}$ & Fisher $\ll$ s exact, $p>0.05$ \\
\hline \multicolumn{4}{|l|}{ Use of chemicals at work } \\
\hline $\begin{array}{l}\text { Yes } \\
\text { NO }\end{array}$ & $\begin{array}{l}20(22.2) \\
70(77.8)\end{array}$ & $\begin{array}{c}0(0) \\
90(100)\end{array}$ & $\chi^{2}=22.5, \mathbf{p} \leq \mathbf{0 . 0 0 1 *}$ \\
\hline \multicolumn{4}{|l|}{ Use of machinery at work } \\
\hline $\begin{array}{l}\text { Yes } \\
\text { NO }\end{array}$ & $\begin{array}{c}90(100) \\
0(0)\end{array}$ & $\begin{array}{c}0(0) \\
90(100)\end{array}$ & $\chi^{2}=180, \mathbf{p} \leq \mathbf{0 . 0 0 1 *}$ \\
\hline
\end{tabular}

$\mathrm{SD}=$ standard deviation, $\quad$ Min =minimum, $\quad \mathrm{Max}=$ maximum,$\quad \mathrm{OR}=$ odds ratio $\mathrm{p}=$ probability, \#Z of Mann Whitney test, $\chi 2=$ chi-square test $\quad$ Yrs $=$ Years $\quad *$ : Statistically significant 
Table (2) stated that most of the studied groups were permanent workers. All the study population worked only morning shifts. One quarter of exposed workers had other jobs beside their work at the marble and granite workshop compared to $(35.6 \%)$ of the comparison group. About one quarter of the marble and granite workers used chemicals at work while no one in the comparison group did with statistically significant difference. Moreover, all marble and granite workers used machines at work compared to the comparison group ( $\mathrm{p}$ value $\leq 0.001$ ).

Table (3): Prevalence of workplace injuries among the studied groups within the past 12 months.

\begin{tabular}{|c|c|c|c|}
\hline \multirow[t]{2}{*}{ Injuries } & $\begin{array}{c}\text { Marble \& } \\
\text { granite workers } \\
\text { No=90 } \\
\end{array}$ & $\begin{array}{c}\text { Comparison } \\
\text { group } \\
\text { No=90 } \\
\end{array}$ & \multirow[t]{2}{*}{ Tests of significance } \\
\hline & No $(\%)$ & No $(\%)$ & \\
\hline $\begin{array}{l}\text { Occurrence of injuries } \\
\text { - None } \\
\text { - One or more } \\
\end{array}$ & $\begin{array}{c}0(0) \\
90(100)\end{array}$ & $\begin{array}{l}78(86.7) \\
12(13.3) \\
\end{array}$ & $\chi^{2}=137.6, \mathbf{p} \leq \mathbf{0 . 0 0 1 *}$ \\
\hline \multicolumn{4}{|l|}{ Types of injuries $^{\# \#}$} \\
\hline - Superficial wound & $90(100)$ & $0(0)$ & $\chi^{2}=180, \mathbf{p} \leq \mathbf{0 . 0 0 1 *}$ \\
\hline - Contusion /bruises & $21(23.3)$ & $0(0)$ & $\chi^{2}=23.7, \mathbf{p} \leq \mathbf{0 . 0 0 1 *}$ \\
\hline - Tear & $20(22.2)$ & $11(12.2)$ & $\begin{array}{c}\chi^{2}=3.1, p>0.05 \\
\text { OR } 2.1(0.9-4.5)\end{array}$ \\
\hline - Laceration & $16(17.8)$ & $0(0)$ & $\chi^{2}=17.5, \mathbf{p} \leq \mathbf{0 . 0 0 1} *$ \\
\hline - Sprain /strain & $4(4.4)$ & $7(7.8)$ & $\begin{array}{c}\chi^{2}=0.8, p>0.05 \\
\text { OR } 0.5(0.1-1.9)\end{array}$ \\
\hline
\end{tabular}

Table (3) displayed that all of the marble and granite workers had one or more injuries in the past year compared to $(13.3 \%)$ of the comparison group with high statistically significant difference $(p \leq 0.001)$. Regarding the types of injuries, the exposed workers had a statistically significant higher prevalence of superficial wounds, contusion/bruises, tear and laceration compared to the control group.

There is no injuries related to using chemicals, may be because the used chemicals were scanty and not harmful; the workers depended during their work on machines. 


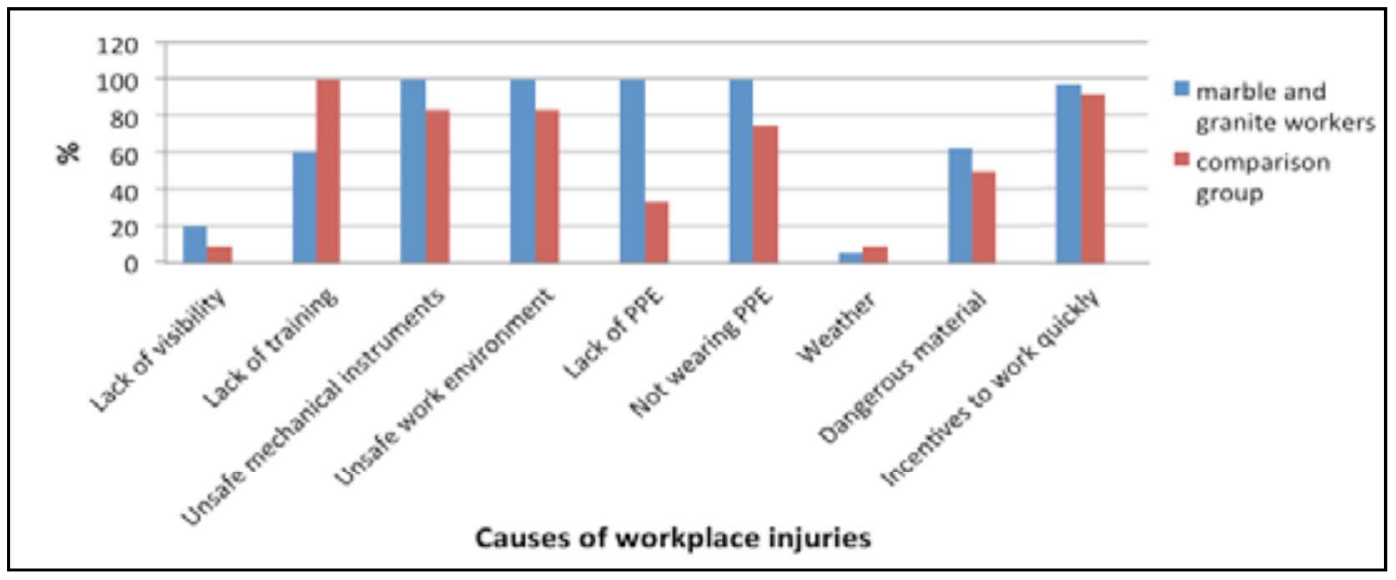

Figure (1): Main causes for workplace injuries as reported by injured subjects among both groups.

Figure (1) illustrates that unsafe working environment, unsafe use of instruments, lack of protective equipment and nonadherence to donning them were the main causes of workplace injuries among all injured workers. While lack of training and incentives to work quickly were the two main causes among the comparison group $(100 \%, 83.3 \%$ and $83.3 \%$ respectively).

Table 4: Predictors of injuries among total studied workers.

\begin{tabular}{|c|c|c|c|c|}
\hline Predictors & $\begin{array}{c}\text { Total } \\
\text { No }=180 \\
\end{array}$ & $\begin{array}{c}\text { Injury } \\
\mathrm{No}_{0}=101(56.1 \%)\end{array}$ & $\begin{array}{c}\text { COR } \\
(95 \% \mathrm{CI}) \\
\end{array}$ & $\begin{array}{c}\text { AOR } \\
(95 \% \mathrm{CI}) \\
\end{array}$ \\
\hline $\begin{array}{c}\text { Age (years) } \\
\cdot<40 \\
\cdot \geq 40 \quad(\mathrm{r})\end{array}$ & $\begin{array}{c}119 \\
61\end{array}$ & $\begin{array}{l}69(58.0) \\
32(52.5)\end{array}$ & $\begin{array}{c}1.161 \\
(0.626-2.153)\end{array}$ & \\
\hline $\begin{array}{l}\text { Residence } \\
\text { • Rural } \\
\text { • Urban (r) }\end{array}$ & $\begin{array}{c}123 \\
57\end{array}$ & $\begin{array}{l}88(71.5) \\
13(22.8)\end{array}$ & $\begin{array}{c}8.51 \\
(4.09-17.69) \text { * }\end{array}$ & $\begin{array}{c}4.43 \\
(\mathbf{1 . 7 4 8 - 1 1 . 2 3 )}\end{array}$ \\
\hline $\begin{array}{l}\text { Level of education } \\
\text { - Illiterate } \\
\cdot \text { Read and write }\end{array}$ & $\begin{array}{c}4 \\
176\end{array}$ & $\begin{array}{l}4(100.0) \\
97(55.1)\end{array}$ & **undefined & \\
\hline $\begin{array}{r}\text { Marital status } \\
\text { - Unmarried } \\
\text { - Married (r) } \\
\end{array}$ & $\begin{array}{c}34 \\
146\end{array}$ & $\begin{array}{l}28(82.4) \\
73(50.0) \\
\end{array}$ & $\begin{array}{c}4.67 \\
(1.82-11.94)\end{array}$ & $\begin{array}{c}6.61 \\
\text { (1.88-23.21)* }\end{array}$ \\
\hline $\begin{array}{ll}\text { BMI } & \\
& \text { - Non-obese } \\
& \text { - Obese (r) }\end{array}$ & $\begin{array}{c}146 \\
34\end{array}$ & $\begin{array}{l}86(58.9) \\
15(44.1)\end{array}$ & $\begin{array}{c}1.82 \\
(0.855-3.855)\end{array}$ & \\
\hline $\begin{array}{c}\text { Family size } \\
\qquad<5 \text { persons }(\mathrm{r}) \\
\cdot \geq 5 \text { persons }\end{array}$ & $\begin{array}{l}94 \\
86\end{array}$ & $\begin{array}{l}46(48.9) \\
55(64.0)\end{array}$ & $\begin{array}{c}1.851 \\
(1.018-3.366)\end{array}$ & \\
\hline
\end{tabular}




\begin{tabular}{|c|c|c|c|c|}
\hline $\begin{array}{c}\text { Family income per month } \\
\text { - Able to save (r) } \\
\text { - Enough } \\
\text { - Indebt }\end{array}$ & $\begin{array}{l}14 \\
84 \\
82\end{array}$ & $\begin{array}{c}1(7.1) \\
44(52.4) \\
56(68.3)\end{array}$ & $\begin{array}{c}1 \\
14.3 \\
(1.79-14.30)^{*} \\
28.0 \\
(3.48-225.58) *\end{array}$ & $\begin{array}{c}1 \\
18.86 \\
(\mathbf{1 . 7 3 - 2 0 5 . 2 ) *} \\
17.71 \\
(\mathbf{1 . 5 8 - 1 9 8 . 4 7 ) *}\end{array}$ \\
\hline $\begin{array}{c}\text { Current smoking habits } \\
\text { • Yes } \\
\cdot \text { NO (r) }\end{array}$ & $\begin{array}{c}101 \\
79\end{array}$ & $\begin{array}{l}78(77.2) \\
23(29.1)\end{array}$ & $\begin{array}{c}\mathbf{8 . 2 5 7 *} \\
(4.216-16.17)\end{array}$ & $\begin{array}{c}\mathbf{7 . 6 9} \\
(1.88-23.21)\end{array}$ \\
\hline $\begin{array}{c}\text { Number of cigs. /day } \\
\cdot \leq 10(\mathrm{r}) \\
\cdot>10\end{array}$ & $\begin{array}{l}25 \\
71\end{array}$ & $\begin{array}{l}17(68.0) \\
57(80.3)\end{array}$ & $1.916(0.688-5.33)$ & \\
\hline Duration of smoking & $\begin{array}{c}15.0 \\
(2.0-36.0) \\
\end{array}$ & $\begin{array}{c}15.0 \\
(2.0-36.0) \\
\end{array}$ & $\begin{array}{c}1.00 \\
(0.953-1.07) \\
\end{array}$ & \\
\hline $\begin{array}{l}\text { Type of contract } \\
\text { • Permanent } \\
\text { - Temporary }(\mathrm{r})\end{array}$ & $\begin{array}{c}156 \\
24\end{array}$ & $\begin{array}{l}88(56.4) \\
13(54.2)\end{array}$ & $1.095(0.462-2.59)$ & \\
\hline Duration of employment (yrs) & $\begin{array}{c}10.0 \\
(3.0-35.0) \\
\end{array}$ & $\begin{array}{c}12.0 \\
(3.0-31.0) \\
\end{array}$ & $\begin{array}{c}1.02 \\
(0.983-1.06) \\
\end{array}$ & \\
\hline Age of joining the job & $23.18 \pm 4.63$ & $21.30 \pm 3.94$ & $\begin{array}{c}0.808 \\
(0.743-0.878)\end{array}$ & \\
\hline $\begin{array}{l}\text { Exposure } \\
\text { • Present } \\
\text { - Absent (r) }\end{array}$ & $\begin{array}{l}90 \\
90\end{array}$ & $\begin{array}{l}90(100) \\
11(12.2)\end{array}$ & $* *$ undefined & \\
\hline $\begin{array}{c}\text { Multiple jobs } \\
\text { - Yes ( r) } \\
\cdot \text { NO }\end{array}$ & $\begin{array}{c}56 \\
124\end{array}$ & $\begin{array}{l}29(51.8) \\
72(58.1)\end{array}$ & $1.289(0.684-2.43)$ & \\
\hline $\begin{array}{c}\text { Direct supervision on work } \\
\text { - Yes } \\
\cdot \text { NO }\end{array}$ & $\begin{array}{c}176 \\
4\end{array}$ & $\begin{array}{l}97(55.1) \\
4(100.0)\end{array}$ & ** undefined & \\
\hline $\begin{array}{c}\text { Chemicals at work } \\
\text { - Yes } \\
\text { • NO }\end{array}$ & $\begin{array}{c}20 \\
160\end{array}$ & $\begin{array}{l}20(100) \\
81(50.6)\end{array}$ & ** undefined & \\
\hline $\begin{array}{c}\text { Machines at work } \\
\text { - Yes } \\
\cdot \text { NO }\end{array}$ & $\begin{array}{l}90 \\
90\end{array}$ & $\begin{array}{l}90(100) \\
11(12.2)\end{array}$ & **undefined & \\
\hline $\begin{array}{l}\text { Model } \chi^{2}=162.69 \mathrm{p}<0.001 * \\
\text { Overall \% predicted }=81.1 \%\end{array}$ & & & & \\
\hline
\end{tabular}

COR: Crude Odds Ratio (bivariate analysis),

AOR: Adjusted Odds Ratio (logistic regression), CI: Confidence Interval r: reference group. yrs: Years *: Statistically significant difference.

**:undefined: odds ratio is undefined as one of the studied cells in 2 by 2 table is zero. 
Table (4) demonstrates the predictors for injuries among the entire studied population. All the marble and granite workers got injured compared to $12.2 \%$ in the comparison group; thus resulting in undefined regression with exposure being a significant predictor for occupational injuries. Workers with low family income and being in debt are 18 times more prone to injures. Current smokers are 7.6 times more likely to get injured than nonsmokers are; unmarried workers are 6.61 times more likely to get injured than married ones; and rural residents are 4.43 times more likely to get injured compared to urban residents. Obesity has no role; the odds of occurrence of injuries are equal in both obese and non-obese as the confidence interval contains 1 .

\section{Discussion}

Marble and granite workshops have high risk of occupational injuries as they use free moving machines with rotating/ moving parts, (Aleksandrova and Timofeeva, 2017). This crosssectional comparative study was held among a group of 90 marble and granite workers and an equivalent group of non-exposed personnel to detect the prevalence of workplace injuries, their predictors and causes among marble and granite workers.

The mean age of workers was $(34.9 \pm 9.1$ years $)$. All of which were males and (71.1\%) married (Table 1). These findings were in line with those suggested by Jaber et al., (2015) in their study among stone saw workers in West Bank-Palestine; they found that the mean age of workers was $(36.85 \pm 11.41$ years). All of whom were males and
(79.2\%) married. AshrafiAsgarabad et al., (2013) in an Irani study among stone carvers of Kerman, also found the mean age of stone carvers was ( $37 \pm 8.3$ years). All being males and about $(89 \%)$ of them were married. The current study showed that most of the exposed workers (93.3\%) were from rural areas (Table 1). That is in accordance with Si et al., (2016), in a study of the prevalence of occupational exposure to respirable crystalline silica, who found that most workers were from remote and low socio-economic areas. The present study showed that most of the marble and granite workers (95.6\%) and the entire comparison group were educated to the primary level or higher (Table 1). This finding was in accordance with Jaber et al., (2015) in his study in West Bank-Palestine, where most of the workers $(86.1 \%)$ were educated to 
primary level or higher. The present work showed that current smokers among marble and granite workers and the comparison group were $82.2 \%, 30 \%$ respectively, with a median duration of smoking for 15 years (Table 1). This finding was in close agreement with Kabir et al., (2018) in a study among stone crushing industries' workers in Bangladesh whofound that $(87.5 \%)$ of them were currently tobacco smokers.

The contemporary study revealed that most of both groups were permanent workers with a median working duration of 12 years (Table 2). These findings agreed with Imani et al., (2015), who found that exposed workers to ceramic products were employed for a longer period (9 years). The current study showed that both groups worked morning shifts. Regarding having other jobs, the exposed group (26.7\%) had other jobs compared to $(35.6 \%)$ of the comparison group .The majority of the two groups had direct supervision at work (Table 2). These findings were in close agreement with that detected by Kabir et al., (2018) in a study among stone crushing industries in Bangladesh, who found that all workers and their comparison group worked morning shifts. About one third of both groups had other jobs beside their current ones. Most of the two groups had direct supervision at work.

Concerning use of chemicals and machines at work, the current study showed that $(22.2 \%)$ of marble and granite workers used chemicals and all used machines at work; while the comparison group didn't use any of them (Table 2). These findings were similar with that declared by Imani et al., (2015), who found that most of the exposed ceramic workers used machines at work.

The prevalence of injuries among marble and granite workers is $100 \%$ (Table 3). This result coincides with Faremi et al., (2014) who carried out a study among Nigerian sawmill workers and Ahmad (2017) in his study of awareness of workplace hazards and preventive measures among sandstone mineworkers in Rajasthan, India; both found that the prevalence of injuries was about $75 \%$. Aliyu and Shehu (2007) carried out a study in Northern Nigeria, found that the prevalence of injuries was $68.9 \%$. This high prevalence concerning the current study might be due to lack of protective measures and hazardous nature of stone cutting work (Wanjiku, 2015). 
Regarding the types of injuries, the present study showed that all marble and granite workers had superficial wounds. They showed high prevalence of contusion/bruises, tear and laceration than the comparison group (Table 3). Wanjiku (2015) in his study of Mutonga quarry, Meru County, Kenya, found that quarrying workers showed similar results. Aliyu and Shehu (2007) in their study among stone quarry workers in Northern Nigeria, found that the mutual type of injury reported among the quarry workers was sticking by hard or sharp objects and cut from stones (68.9\%).

The current work stated that the main causes of workplace injuries among marble and granite workers were unsafe working environment, using instruments unsafely, lack of protective equipment and nonadherence to donning them (Figure 1). Matched with these results, Kunar et al., (2008) in their study on workers from underground coal mines in India, found that nearly half of injured workers reported the main reasons of occupational injuries as unsafe mechanical instruments and using dangerous materials. Discussing each item separately, the current work showed that most of marble and granite workers $(92.2 \%)$ compared to $(23.3 \%)$ of the comparison group reported lack of using personal protective measures (Figure 1). This finding was in unity with that suggested by Wanjiku (2015) and Apenteng et al., (2016) who found that the majority of the workers $(90 \%)$ did not use (PPEs) with a prevalence of ( $90 \%$ and $74.8 \%$ respectively). The reasons of nonuse personal protective equipment among marble and granite processing workers might be due to irregular supply and lack of motivation or discomfort on using these devices. A good solution is to involve employees in the selection of equipments (Chemscape, 2019)

Up to our knowledge, previous researchers discussed only the causes not the predictors for injuries. The current study will try to explain the predictive factors from point of view of occupational health and safety. It revealed that workers with low family income (being in debt) are 18 times prone to injuries than those who can save (Table 4). This contradicts the results of Huang and Friedman (2020) who found no association between family income and work-related injuries. Current study results may be explained by the positive association between low income and low educational as well as social levels 
(American psychological Association, 2020). The existing study found that current smokers to be 7.6 times prone to work-related injuries than nonsmokers (Table 4). Jafari and his colleagues (2019) in their study about relationships between certain individual characteristics and occupational accidents among Petrochemical Company workers, found an association between accidents and smoking habit, but it was not one of the predictive factors. This may be due to difference in the working nature. Unmarried workers are 6.61 times liable to injuries more than married (Table 4). This result is in line with a study performed about accident risk, gender, family status and occupational choice in the UK (Grazier and Sloane, 2008).

Limitation of the study: Being a convenience small sample size, its results lack external validity. Nevertheless, several scientific scrutiny's such as pre-testing of tools, random sampling, development of tools using previous literature, informed consent processes, statistical analysis, and discussion of findings in the context of relevant literature were employed to minimize biases. Future research is recommended to study other health effects of marble and granite processing on the health of workers such as musculoskeletal, respiratory, dermal and hematological effects.

\section{Conflict of Interest}

No conflict of interest is declared by all authors.

\section{Funding}

This study did not receive any funding from any source.

\section{Acknowledgement}

The authors would like to acknowledge the contribution of all individuals who participated in this study.

\section{References}

1. Ahmad A (2017): Awareness of workplace hazards and preventive measures among sandstone mineworkers in Rajasthan, India: A cross-sectional study. Health Soc Sci; 2 (1): 69-82.

2. Aleksandrova AJ and Timofeeva SS (2017): Risk Assessment for Stonecutting Enterprises. In IOP Conference Series: Mater Sci Eng; 189 (1): 012029.

3. Aliyu AA and Shehu AU (2007): Occupational hazards and safety measures among stone quarry workers in Northern Nigeria. Nigerian Medical Practitioner; 50 (2):42-7.

4. American Psychological Association (2020): Education and Socioeconomic Status. Available at: https://www.apa.org/pi/ses/resources/ publications/education

5. Amponsah-Tawiah $\mathrm{K}$ and Mensah $\mathrm{J}$ (2016): Occupational health and safety and 
organizational commitment: Evidence from the Ghanaian mining industry. Saf health work; 7 (3): 225-30.

6. Apenteng J, Quaye G, Oppong E and OseiAsare C (2016): The risk of pulmonary disease and other health hazards among small scale stone quarry workers: a study at Miosto in the Ningo-Prampram District of Ghana. Int J Dev Res; 6 (10): 9739- 47.

7. AshrafiAsgarabad A, SamarehFekri M, Khanjani N and GhotbiRavandi M (2013): Exposure to particles and respiratory symptoms in stone carvers of Kerman, Iran. J Occup Health Epidemiol; 2 (4): 146- 56.

8. Brown R (2020): Comparative analysis of work-related injuries and illnesses in industrial locations in the United States between 20072011 (Doctoral dissertation, Rutgers UniversitySchool of Health Professions). Available at: https://rucore.libraries.rutgers.edu/rutgerslib/64640/

9. Chemscape (Safety Technologies) (2019): The Limitations of PPE as a Hazard Control Method. Available at: https://www.chemscape.com/ blog/limitations-ppe-hazard-control-method

10. do Couto A, Baptista JS, Barkokébas B and da Silva I (2018): Impacts of accidents with workers in rock processing industries: Short review. In Occupational Safety and Hygiene VI: Book chapters from the 6th International Symposium on Occupation Safety and Hygiene (SHO 2018), Guimarães, Portugal. 377. CRC Press. DOI: https://doi.org/10.1201/9781351008884

11. El-Gammal M, Ibrahim M, Badr S, Asker S and El-Galad N (2011): Health risk assessment of marble dust at marble workshops. J Nat Sci; 9 (11): 144- 54.

12. Faremi FA, Ogunfowokan AA, Mbada C, Olatubi MI and Ogungbemi AV (2014): Occupational hazard awareness and safety practices among Nigerian sawmill workers. Int J Med Sci Public Health; 3 (10):1244-8.

13. Grazier S and Sloane PJ (2008): Accident risk, gender, family status and occupational choice in the UK. Labour Econ; 15 (5): 938-57.

14. Huang $Z$ and Friedman LS (2020): Occupational injury surveillance pyramid description and association of medical care utilization with low income among work $\square$ related injuries. Am J Ind Med; 63 (3): 249-57.

15. Imani $M$, Heidari $H$, Rahimifard $H$ and Mahdinia M (2015): Assessment of occupational exposure to silica dust and respiratory effects in exposed workers in one of the ceramic products industry. Sci J (CSJ); 36 (4): 1894- 98.

16. ILO (International Labour Organization) (2014): Global trends on occupational accidents and diseases, World Day for Safety and Health at Work. Available at: https:// www.ilo. org/ legacy /english /osh /en/story _content/ external_files/fs_st_1-ILO_5_en.pdf (viewed 5 May 2018).

17. Jaber H, Mohamed M, El-Safty A, El-Salamoni $\mathrm{O}$ and Ibrahim H (2015): Prevalence and risk factors of noise induced hearing loss and other work-related health problems among stone saw workers in West Bank-Palestine. Med J Cairo Univ; 83 (2): 33-42.

18. Jafari MJ, Barkhordari A, Eskandari D and Mehrabi Y (2019): Relationships between certain individual characteristics and occupational accidents. Int J Occup Saf Ergo; 25 (1): 61-5.

19. Kabir E, Islam A and Taufikuzzaman Md (2018): An investigation into respiratory health problems of workers at stone crushing industries in Bangladesh. J Health Res; 32 (2): 172-8.

20. Kandil A and Selim TH (2006): Characteristics of Marble Industry in Egypt: Structure, Conduct, and Performance. Int Bus Econ Res J; 4 (3): 2-33.

21. Kunar BM, Bhattacherjee A and Chau N (2008): Relationships of job hazards, lack of knowledge, alcohol use, health status and risktaking behavior to work injury of coal miners: A case $\square$ control study in India. J occup health; 50 (3): 236-44.

22. OSHA (Occupational Safety and Health 
Administration) (2013): Hazards of operating unguarded stone cutters and splitters in landscaping and other worksites, U.S. Department of Labor. Available at: https:// www. osha.gov/dts/shib/shib01252013.html.

23. OSHA (Occupational Safety and Health Administration) (2001): 1904.5(a) Recording and reporting occupational injuries and illness. Available at https://www.osha.gov/ pls/oshaweb/owadisp.show_document?p_ table $=$ STANDARDS

24. Si S, Carey R, Reid A, Driscoll T, Glass, D and Peters S et al. (2016): The Australian Work Exposures Study: Prevalence of occupational exposure to respirable crystalline silica. Ann Occup Hyg; 60 (5): 631-7.

25. Tadesse $T$ and Kumie A (2007): Prevalence and factors affecting work-related injury among workers engaged in Small and Medium-scale industries in Gondar wereda, North Gondor zone, Amhara Regional State, Ethiopia. Ethiop J Health Dev; 21 (1): 25-34.

26. Trade Development Authority of Pakistan (2011): A report on marble \& granite. Available at: https://www.tdap. gov. pk /doc_reports / tdap_ report_on _marble_ and_ granite.pdf (viewed 4 May 2018).

27. Wanjiku MW (2015): Occupational health and safety hazards associated with quarrying activities; A case of Mutonga Quarry, Meru County, Kenya (Master dissertation of Science in Public Health, Jomo Kenyatta University of Agriculture and Technology, Kenya. Available at: http://ir.jkuat.ac.ke/handle/123456789/1710 